\title{
PISMA ORYBAZJUSZA JAKO ŹRÓDLO INFORMACJI O POŻYWIENIU LUDZI W PÓŹNYM CESARSTWIE RZYMSKIM ${ }^{1}$
}

Celem niniejszego artykułu jest omówienie najważniejszych zagadnień związanych z dorobkiem pisarskim Orybazjusza z zakresu medycyny (okoliczności jego powstania, budowy, treści, źródeł i recepcji), a także bliższe, bardziej szczegółowe przedstawienie tych fragmentów jego pism, które poświęcone zostały produktom spożywczym, uzyskiwanym z nich pokarmom, oraz ich właściwościom medycznym i dietetycznym. Zanim jednak przejdziemy do właściwego tematu, pragniemy krótko przypomnieć postać autora, którego dziełami zamierzamy się zająć.

Orybazjusz urodził się prawdopodobnie w latach 20-tych IV w. w Pergamonie, który stanowił jeden z ważniejszych ośrodków medycznych ówczesnego świata. Wyrósłszy w specyficznej miejscowej atmosferze, młodzieniec wszedł na drogę kariery lekarskiej, rozpoczynając w swoim mieście naukę zawodu, którą kontynuował z powodzeniem w egipskiej Aleksandrii. Powróciwszy, po kilku zapewne latach, w rodzinne strony, poznał w bliżej nieznanych okolicznościach przyszłego cesarza Juliana Apostatę, z którym zaprzyjaźnił się, dzieląc - jak się możemy domyślać - zainteresowania i poglądy. Gdy w 355 r. Julian został mianowany cezarem i wysłany do Galii, Orybazjusz zdecydował się podążyć za swym wysoko urodzonym przyjacielem $\mathrm{w}$ charakterze jego osobistego lekarza i jako jeden $z$ niewielu zaufanych ludzi towarzyszył mu tam aż do roku 361. Następnie, w wyniku krótkotrwałej wojny domowej między Julianem a Konstancjuszem II (361 r.), Orybazjusz znalazł się znów, wraz ze swoim zwycięskim protektorem, we wschodniej części Cesarstwa Rzymskiego. W roku 363 wyruszył razem z Apostatą i jego armią na Persję i był obecny przy ciężko rannym cesarzu, próbując bezskutecznie uratować mu życie. Zmiany, jakie po śmierci imperatora nastąpiły na szczytach

${ }^{*}$ Mgr Krzysztof Jagusiak - doktorant przy Katedrze Historii Bizancjum w Instytucie Historii na Wydziale Filozoficzno-Historycznym Uniwersytetu Łódzkiego; e-mail: krzysztof_jagusiak@o2.pl.

** Dr hab. Maciej Kokoszko, prof. UŁ - kierownik Katedry Historii Bizancjum w Instytucie Historii na Wydziale Filozoficzno-Historycznym Uniwersytetu Łódzkiego; e-mail: mkokoszko@ komandor.pl.

${ }^{1}$ Artykuł został napisany w związku z grantem 2011/01/BHS3/01020. 
władzy, spowodowały zdecydowany zwrot w życiu Orybazjusza. Nowi władcy Rzymu byli zdecydowanie mniej przychylni obciążonemu w ich oczach współpracą z poprzednim reżimem Pergamończykowi, który - wróciwszy wraz z wycofującą się z Persji armią na terytorium rzymskie - został w niejasnych okolicznościach skazany na wygnanie i konfiskatę majątku. Przez kilka lub kilkanaście lat przebywał na północ od dolnego biegu Dunaju, wśród miejscowej ludności prowadząc $\mathrm{z}$ wielkim powodzeniem swoją lekarską praktykę. Gdy został wreszcie odwołany z wygnania, osiadł na stałe w Konstantynopolu, gdzie dalej trudnił się leczeniem ludzi, ustatkował się i założył rodzinę. Zmarł, otoczony szacunkiem, prawdopodobnie pod koniec IV, lub w początkach V stulecia ${ }^{2}$.

Błyskotliwa kariera Orybazjusza nie była jednak najważniejszym czynnikiem, który sprawił, że jego imię przetrwało do naszych czasów. Unieśmiertelniła je w znacznie większym stopniu dopiero jego działalność pisarska, którą szerzej pragniemy omówić w niniejszym artykule. Pergamończyk napisał kilka dzieł, z których znaczna część przetrwała do naszych czasów, inne zaś znamy tylko z informacji przekazanych nam przez późniejszych autorów. Dzieła te zaprezentujemy poniżej w porządku, o ile to możliwe, chronologicznym.

Pierwszą pracą Orybazjusza, o jakiej wiemy, był nie zachowany traktat medyczny sporządzony przezeń na wyraźne życzenie Juliana Apostaty, podczas pobytu obu wymienionych w $\mathrm{Galii}^{3}$. O dziele tym wspomniał gdzie indziej sam autor ${ }^{4}$, poza tym wymienił je również Focjusz (patriarcha Konstantynopola w latach 858-867, 877-886) w swojej Bibliotece ${ }^{5}$. Wedle przekazanych nam w ten sposób informacji, było ono wyciągiem z medycznych traktatów Galena ${ }^{6}$, mającym w zamyśle Orybazjusza ułatwić naukę mniej zdolnym

${ }^{2} \mathrm{Na}$ temat życia Orybazjusza, przebiegu jego kariery i związków z Julianem Apostatą zob. np. H.O. Schröder, Oreibasios, RE Suppl. VII 797-812; B. Baldwin, The Career of Oribasius, „Acta Classica" 18 (1975) 85-97; M. Grant, Introduction, w: Oribasius, Dieting for an Emperor, A Translation of Books 1 and 4 of Oribasius' „Medical Compilations” with an Introduction and Commentary, ed. M. Grant, Leiden 1997, 1-4; K. Jagusiak - M. Kokoszko, Życie i kariera Orybazjusza w świetle relacji źródłowych, „Przegląd Nauk Historycznych” 10 (2011) nr 1, 5-21.

${ }^{3}$ Wynika to ze słów samego Pergamończyka napisanych w przedmowie do innego jego dzieła (por. Oribasius, Collectiones medicae. Prologus 1, 1 - 4, 7; w niniejszym artykule posługiwano się wydaniem: Oribasii Collectionum medicarum reliquiae, ed. I. Raeder, I-IV, Lipsiae - Berolini 19281933). Można by zatem datować dzieło na lata 356-361. Jednakże, wedle Focjusza (Bibliotheca cod. 216), autor zwraca się tam do Juliana słowem „Autokrator”. Na tej podstawie H.O. Schröder (Oreibasios, kol. 800) przyjmuje, że Orybazjusz napisał je dopiero w 361 r., po tym, gdy Apostata został jedynowładcą Imperium. Sądzimy jednak, że mogło to równie dobrze nastąpić już w roku 360, po paryskiej aklamacji Juliana.

${ }^{4}$ Orybazjusz, Collectiones medicae. Prologus 1, 1-2, 1.

${ }^{5}$ Por. Photius, Bibliotheca cod. 216.

${ }^{6}$ Galen z Pergamonu (ok. 130 - ok. 200/210) był jednym z najwybitniejszych lekarzy starożytności, który prócz dużej, wedle jego własnych słów, sławy zdobytej dzięki wysokim umiejętnościom praktycznym, swoją unikatową pozycję w świecie medycyny zawdzięczał ogromnej spuściź- 
adeptom sztuki lekarskiej, a także stanowić podręczne źródło wiadomości dla tych, którzy nie mają czasu, lub możliwości zajrzeć do ksiąg omawiających interesujące ich zagadnienie w bardziej obszerny sposób. Nie wiemy, jak Orybazjusz rozłożył materiał w owym dziele, poza tym, że na początku omówił właściwości pokarmów ${ }^{7}$. Nie wiemy również, z jakich konkretnych prac Galena korzystał, ani też w ilu księgach zawarł swoją kompilację.

Osobną kwestią pozostają zamiary władcy, wymienionego wprost jako osoba, która dała impuls do sporządzenia traktatu. Być może stworzenie tego dzieła nie powinno być traktowane jedynie jako forma upustu naukowych pasji Juliana, ale było w jego zamyśle pierwszą próbą włączenia medycyny, tradycyjnie kojarzonej z dawnymi kultami, w plany przywrócenia pogaństwu dominującej pozycji w państwie rzymskim ${ }^{9}$ Bez względu na intencje wład-

nie literackiej, jaką po sobie zostawił (obejmującej również traktaty filozoficzne) i jaka w dużej części przetrwała do naszych czasów. W swych dziełach poruszał kwestie związane $\mathrm{z}$ wieloma, często odległymi od siebie, problemami lecznictwa, w tym również interesującej nas szczególnie dietetyki. Jego postawa, związana z oddaniem poglądom hipokratejskim, czy teorii humoralnej, utrwalona została przez Orybazjusza i późniejszych autorów. Skomplikowane, pełne niuansów, trudności interpretacyjnych i pozornych sprzeczności, opinie Galena wyewoluowały w zjawisko nazywane galenizmem i dominowały w medycynie aż po wczesną epokę nowożytną. Por. np. J. Mewaldt, Galenos (3), RE VII 578-589; F.H. Garrison, History of Medicine, Philadelphia 1929, 112-115; G. Sarton, Galen of Pergamon, Lawrence Ks. 1954, passim (spec. 15-29); E.D. Phillips, Greek Medicine, London 1973, 172-181; L.T. Pearcy, Galen and Stoic Rhetoric, GRBS 24 (1983) nr 3, 259-272; J. Scarborough, Early Byzantine Pharmacology, DOP 38 (1984) 213-235; L.M. Zimmerman - I. Veith, Great Ideas in the History of Surgery, San Francisco 1993, 39-44; M. Grant, Galen on Food and Diet, LondonNew York 2000, 1-11 (Introduction); T. Tieleman, Galen, w: Antike Medizin. Ein Lexikon, München 2005 (= AML), 315-319; I. Garofalo, Galenismus, AML 319-321; K.H. Leven, Galenkritik, AML 321-322; M. Kokoszko, Ryby i ich znaczenie w życiu codziennym ludzi późnego antyku i wczesnego Bizancjum (III-VII w.), Łódź 2005, 12-13.

${ }^{7}$ Stwierdza to Focjusz (Bibliotheca cod. 217) przy omówieniu drugiego Orybazjuszowego dzieła-Collectiones medicae.

${ }^{8}$ Odnośny fragment tekstu Biblioteki Focjusza jest uszkodzony, zaś Orybazjusz w Collectiones medicae nie wspomina nic na ten temat. Natomiast pewną wskazówką dotyczącą rozmiarów dzieła jest wzmianka zawarta w Bibliotece Focjusza (cod. 221), który, omawiając zachowane do naszych czasów dzieło medyczne Aecjusza z Amidy, napisał, iż jest ono mniejsze od omawianego tu przez nas pisma Orybazjusza.

${ }^{9}$ Należy pamiętać, że związany z medycyną kult Asklepiosa stanowił bardzo silną konkurencję dla chrześcijaństwa i jego wzmocnienie było po myśli Juliana (por. Contra Galilaeos 235B-C; $\mathrm{w}$ niniejszym artykule korzystano z wydania: The Works of the Emperor Julian, with an English translation by W.C. Wright, III, London - Cambridge Mass. 1969, oraz przekładu polskiego A. Pająkowskiej: Julian Apostata, Przeciw Galilejczykom, Fontes Historiae Antiquae 24, Poznań 2012). Por. R. de Lucia, Doxographical Hints in Oribasius' ,'Collectiones medicae”, w: Ancient Histories of Medicine. Essays in Medical Doxography and Historiography in Classical Antiquity, ed. P.J. van der Eijk, Leiden 1999, 474. Orybazjusz był wprawdzie lekarzem świeckim, jednak w powszechnej świadomości chrześcijan zawód medyka, również nie związanego ze świątynią, kojarzony był odruchowo z pogaństwem. W tym sensie stymulowanie przez Apostatę tworzenia dzieł medycznych można odebrać jako jeden z elementów jego antychrześcijańskiej postawy. 
cy, traktat Orybazjusza przypadł mu do gustu ${ }^{10}$, choć, jak miała to pokazać najbliższa przyszłość, nie wyczerpał jego planów tworzenia dzieł o tematyce medycznej.

Niedługo bowiem po tym, gdy ukończony został wyciąg z pism Galena, Julian wyznaczył Orybazjuszowi kolejne, poważniejsze, pisarskie zadanie. Miał on tym razem sporządzić kompilację, na którą składałyby się nie tylko prace jego wybitnego II-wiecznego krajana, ale także najwartościowsze pisma innych lekarzy stanowiące uzupełnienie i rozszerzenie wywodu ${ }^{11}$. Pergamończyk musiał pracować nad powierzonym mu zadaniem intensywnie i sumiennie, bowiem w okresie wynoszącym mniej niż trzy i pół roku, kiedy często zmieniał miejsca pobytu i nie zawsze miał dogodne warunki do pisania, a przede wszystkim zbierania i opracowywania materiałów ${ }^{12}$, stworzył monumentalne dzieło liczące najprawdopodobniej $70 \mathrm{ksiąg}^{13}$, które przyjęło się określać jako Collectiones medicae.

Zachowane do naszych czasów fragmenty omawianego dzieła obejmują zaledwie 25 woluminów. Pragniemy w bardziej szczegółowy sposób przedstawić zawartość pierwszych pięciu spośród nich, w których Orybazjusz zajął się omówieniem kwestii związanych z dietetyką.

W pierwszej księdze, podzielonej na sześćdziesiąt pięć znacznie różniących się od siebie objętością paragrafów, opisywany przez nas lekarz skupił się na prezentacji różnych gatunków zbóż (kilku odmian pszenicy: zwyczajnej, samopszy, płaskurki, orkiszu ${ }^{14}$, by następnie przejść do omówienia właściwości jęczmienia ${ }^{15}$, prosa $^{16}$, włośnicy ${ }^{17}$, owsa ${ }^{18}$ i ryżu ${ }^{19}$ ) i uzyskiwanych z nich w trak-

${ }^{10}$ Tak przynajmniej twierdzi sam Orybazjusz we wstępie do Collectiones medicae (Prologus $2,1-3,1)$.

${ }^{11}$ Por. Oribasius, Collectiones medicae. Prologus 2, 1 - 3, 1; Photius, Bibliotheca cod. 217.

12 Zakładamy, że Orybazjusz pracował nad tą publikacją od 360/361 r., czyli po zakończeniu poprzedniego dzieła. Skończył zaś najpóźniej w pierwszej połowie 363 r., bowiem z treści wynika, że cesarz Julian wciąż był wówczas wśród żywych. W tym czasie przebywał w Galii, na Bałkanach, w Konstantynopolu, Antiochii Syryjskiej i w Persji, co w oczywisty sposób musiało utrudniać mu pracę.

${ }^{13}$ Nie wszystkie przetrwały do naszych czasów (por. niżej), w związku z czym przy ustaleniu ich liczby trzeba polegać na informacjach samego Orybazjusza zawartych gdzie indziej (Oribasius, Synopsis ad Eustathium filium. Prologus 1, 1-3, ed. I. Raeder: Oribasii Synopsis ad Eustathium. Libri ad Eunapium, Lipsiae - Berolini 1926 (reprint Amsterdam 1964), 5), przekazie Pawła z Eginy (Paulus Aegineta, Prooimion, ed. I.L. Heiberg, pars prior: Libri I-IV, Lipsiae - Berolini 1921, 4) i Focjusza (Bibliotheca cod. 217). Wszyscy oni piszą o 70-ciu księgach. Natomiast Księga Suda (Suidae Lexicon, 'Opєıß́́бıьo,, o, 543, 3-4, ed. A. Adler, III, Lipsiae 1938, 555) podaje liczbę 72 ksiąg Collectiones medicae.

${ }^{14}$ Por. Oribasius, Collectiones medicae I 2, 1, 1 - 14, 6; I 4, 1, 1-3; I 13, 1, 1 - 6, 5.

${ }^{15}$ Por. tamże I 10, 1, 1-2, 4; I 11, 1, 1 - 2, 3.

${ }^{16}$ Por. tamże $15,1,1-4,4$.

${ }^{17}$ Por. tamże I 15, 1, 1 - 4, 4.

${ }^{18}$ Por. tamże I 14, 1, 1 - 2, 5.

${ }^{19}$ Por. tamże I 16, 1, 1-2. 
cie różnych procesów produktów spożywczych $\left(\mathrm{kasz}^{20}\right.$, placków $^{21}$, chlebów ${ }^{22}$, ciast $^{23}$ ) wraz z ich charakterystyką medyczną. Następnie zajął się opisem charakterystycznych cech licznych warzyw i owoców stanowiących podstawę, bądź cenne urozmaicenie czwartowiecznego jadłospisu, takich jak groch ${ }^{24}$, fasola ${ }^{25}$, soczewica $^{26}$, ciecierzyca $^{27}$, bób $^{28}$, wyka ${ }^{29}$, melon $^{30}$, ogórek $^{31}$, figa $^{32}$, dynia $^{33}$, jeżyna $^{34}$, brzoskwinia ${ }^{35}$, jabłko $^{36}$, śliwka ${ }^{37}$, pigwa $^{38}$, kozieradka $^{39}$, łubin ${ }^{40}$, szałwia $^{41}$, sezam $^{42}$, daktyl ${ }^{43}$, migdal ${ }^{44}$, gruszka ${ }^{45}$, granat ${ }^{46}$, kapar $^{47}$, czy tak dzisiaj jednoznacznie kojarzące się z obszarem śródziemnomorskim winorośl ${ }^{48}$ i oliwki ${ }^{49}$. Jeden paragraf poświęcony został właściwościom mięsa różnych zwierząt: świni, kozy, owcy, kilku gatunków ptaków, w tym kury i gołębia, oraz niektórych owoców morza, zmieniającym się w zależności od pory roku, w której jest ono pozyskiwane $^{50}$. Sporządzając swoje opisy, Orybazjusz korzystał przede wszystkim z prac Galena (głównie z dzieła znanego pod łacińskim tytułem De alimentorum facultatibus, jak można wnosić na podstawie dokonanego przez nas porówna-

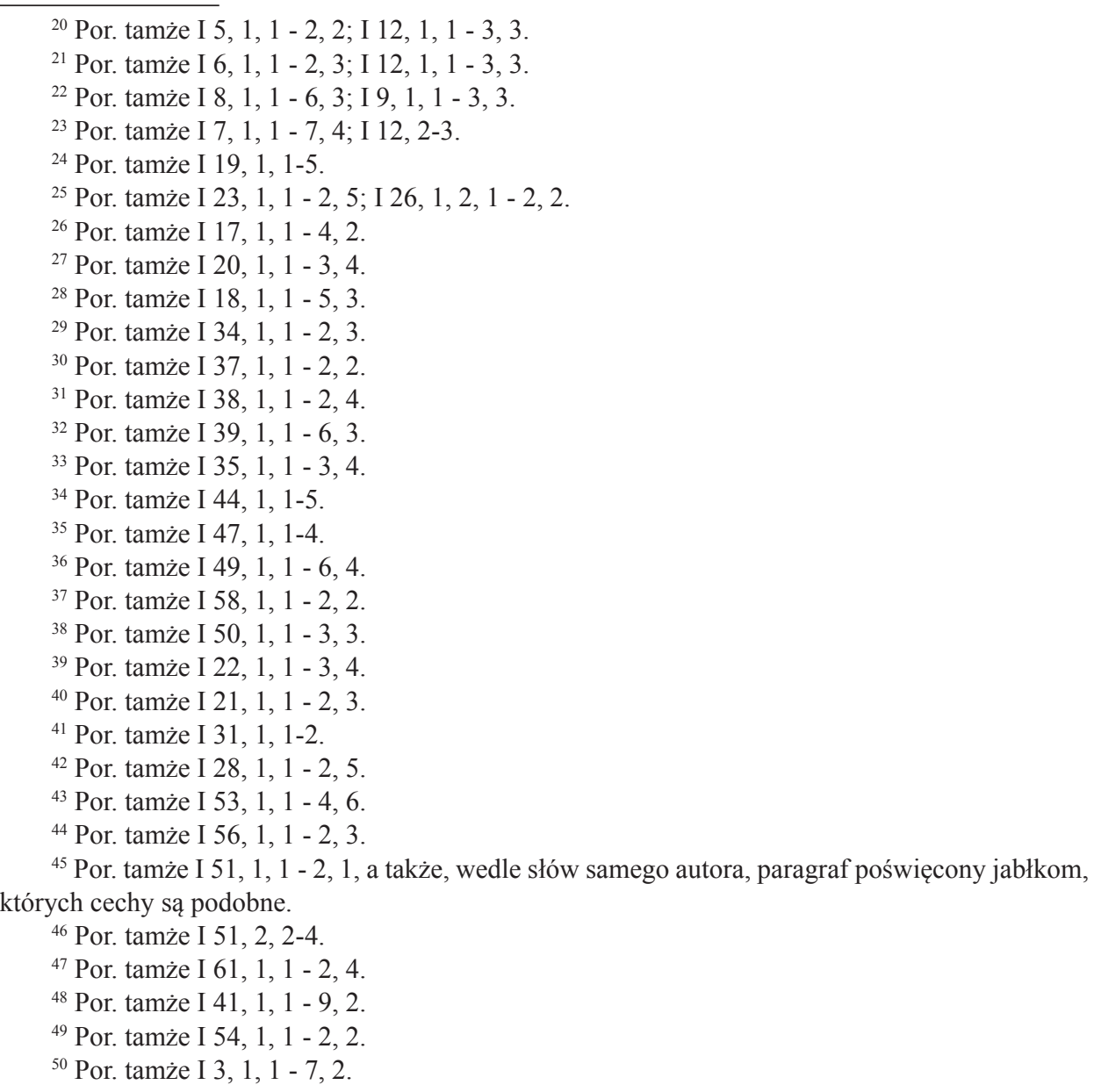


nia obu tekstów), a poza tym z pism Atenajosa z Attalii ${ }^{51}$ i Rufusa z Efezu ${ }^{52}$, o czym kilkakrotnie poinformował swoich czytelników, umieszczając imiona wspomnianych lekarzy w tytułach niektórych paragrafów, niekiedy zaś podając nawet numer cytowanej księgi.

Druga księga Collectiones medicae jest przede wszystkim zbiorem informacji o trzech różnych grupach pokarmów: warzywach (co stanowi kontynuację rozważań zawartych w księdze pierwszej) takich jak sałata ${ }^{53}$, burak $^{54}$, kapusta $^{55}$, szczaw $^{56}$, rzodkiew $^{57}$, cebula $^{58}$, czosnek $^{59}$, por $^{60}$, pokrzywa $^{61}$, bazylia ${ }^{62}$, szparag $^{63}$, marchew ${ }^{64}$, dalej o produktach uzyskiwanych z uboju zwierząt, takich jak nerki ${ }^{65}$, jądra ${ }^{66}$, mózg ${ }^{67}$, szpik kostny ${ }^{68}$, tłuszcz ${ }^{69}$, o podrobach zwierząt

${ }^{51}$ Chodzi tu o lekarza z czasów cesarzy Klaudiusza i Nerona (poł. I w.), założyciela własnej szkoły nazywanej szkołą pneumatyczną. Uzależniał on zdrowie i chorobę od stanu powietrza (pneumy) oraz zmieszania się czterech jakości: ciepła, wilgoci, zimna i suchości w organizmie. Miał szczególną baczność na stosowanie odpowiedniej diety, która była konieczna do utrzymania równowagi pomiędzy wspomnianymi czterema jakościami. Swoje poglądy zawarł w obszernym, liczącym 30 ksiąg, i dość dobrze ocenianym przez Galena, a później Orybazjusza, dziele, które nie przetrwało do naszych czasów i którego tytułu nie znamy. Orybazjusz powołuje się na niego wielokrotnie. Por. M. Wellmann, Athenaios aus Attalia, RE II 2034-2036; E. Kulf, Untersuchungen zu Athenaios von Atteleia. Ein Beitrag zur antiken Diätetik, Göttingen 1970, passim; K.H. Leven, Athenaios v. Attaleia, AML 119-120.

${ }^{52}$ Rufus z Efezu (I/II w.) - jeden z najwybitniejszych greckich lekarzy starożytnych, znakomity praktyk i teoretyk zarazem. Dokonał jako pierwszy kilku istotnych obserwacji dotyczących ludzkiej anatomii, z których część rozwinął później Galen. Był zwolennikiem teorii humoralnej, jednakże pozostał niezależny wobec konkurujących ze sobą szkół medycznych. Pozostawił po sobie wiele dzieł poświęconych rozmaitym zagadnieniom z zakresu lecznictwa. Obficie czerpały z nich następne pokolenia adeptów sztuki medycznej. Jego spuścizna znana jest obecnie w większości dzięki wyciągom sporządzonym przez późniejszych autorów, jak Orybazjusz. Por. H. Gossen, Rufus (18), RE I/1 (2. Reihe) 1207-1212; A. Sideras, Einleitung, w: Rufus Ephesius, De renum et vesicae morbis, edidit et in linguam Germanicam vertit A. Sideras, Berlin 1977, 58-69; A. Bednarczyk, Medycyna i filozofia w starożytności, Warszawa 1999, 543 i 566 (nota 180); S. Ihm, Rufus v. Ephesos, AML 759-760.

${ }^{53}$ Por. Oribasius, Collectiones medicae II 1, 1-4.

${ }^{54}$ Por. tamże II 4, 1, 1 - 2, 4.

${ }^{55}$ Por. tamże II 5, 1, 1 - 3, 2.

${ }^{56}$ Por. tamże II 8, 1, 1-3; II 9, 1, 1-3.

${ }^{57}$ Por. tamże II 26, 1, 1-2.

${ }^{58}$ Por. tamże II 27, 1, 1 - 4, 5.

${ }^{59}$ Por. tamże.

${ }^{60}$ Por. tamże.

${ }^{61}$ Por. tamże II 14, 1, 1-2.

${ }^{62}$ Por. tamże II 16, 1, 1-3.

${ }^{63}$ Por. tamże II 17, 1, 1 - 3, 2.

${ }^{64}$ Por. tamże II 23, 1,1 - 3, 3 .

${ }^{65}$ Por. tamże II $33,1,1$.

${ }^{66}$ Por. tamże II 34, 1, 1-3.

${ }^{67}$ Por. tamże II 35, 1, 1 - 3, 3 .

${ }^{68}$ Por. tamże II 36, 1, 1 - 2, 3.

${ }^{69}$ Por. tamże II 38, 1, 1-2. 
lądowych i skrzydlatych ${ }^{70}$, wreszcie o rybach (okoniu morskim ${ }^{71}$, barwenie $^{72}$, wargaczu $^{73}$, babce czarnej ${ }^{74}$, a także gatunkach określanych $\mathrm{w}$ tekście jako „wielkie ryby" ${ }^{15}$ ), ich konserwach ${ }^{76}$ i o owocach morza (skorupiakach ${ }^{77}$, głowonogach $^{78}$, mięczakach ${ }^{79}$ ). Informacje te uzupełnione są krótkimi passusami na temat mleka (w tym również zsiadłego, a także, w jednym przypadku sera) ${ }^{80}$, miodu $^{81}$ i siły tkwiącej w pożywieniu ${ }^{82}$. Licząca sześćdziesiąt dziewięć paragrafów księga powstała na podstawie wypisów z prac Galena, przede wszystkim wspomnianej wyżej De alimentorum facultatibus ${ }^{83}$, które Orybazjusz uzupełnił rozważaniami znalezionymi w dziełach Ksenokratesa ${ }^{84}$, Rufusa z Efezu, Mnesitheosa z Kyzikos (lub z Aten) ${ }^{85}$, Atenajosa z Attalii i Filotyma ${ }^{86}$.

Trzecia księga omawianego dzieła różni się od obydwu poprzednich sposobem przedstawienia informacji. W jej trzydziestu czterech paragrafach Pergamończyk odszedł od omawiania właściwości, uszeregowanych jeden pod drugim, pojedynczych produktów spożywczych na rzecz przyglądania się w kolejnych partiach jedzeniu pogrupowanemu na podstawie posiadanych przez nie cech i jego oddziaływania na organizm ludzki. Oto bowiem zajął się najpierw dietą tuczącą i odchudzającą ${ }^{87}$, by następnie przejść do omówienia pożywienia

${ }^{70}$ Por. tamże II 39, 1, 1 - 6, 4; II 44, 1, 1 - 5, 4.

${ }^{71}$ Por. tamże II 47, 1, 1-4.

${ }^{72}$ Por. tamże II $48,1,1-3,4$.

${ }^{73}$ Por. tamże II 49, 1, 1 - 2, 3.

${ }^{74}$ Por. tamże II 50, 1, 1 - 3, 4 .

${ }^{75}$ Por. tamże II 57, 1, 1-4. Na temat pojęcia „,wielkich ryb” i szerokości jego zakresu gatunkowego zob. Kokoszko, Ryby i ich znaczenie, s. 155-156.

${ }^{76}$ Por. Oribasius, Collectiones medicae II 58, 132, 3 - 147, 4; II 58, 147, 5 - 152, 6.

${ }^{77}$ Por. tamże II 53, 1, 1 - 5, 5; II 54, 1, 1 - 4, 2.

${ }^{78}$ Por. tamże II 55, 1, 1 - 2, 5.

${ }^{79}$ Por. tamże II 58, 49, 5 - 132, 2.

${ }^{80}$ Por. tamże II 59, 1, 1 - 14, 5; II 60, 1, 1 - 3, 2; II 61, 1, 1 - 10, 2.

${ }^{81}$ Por. tamże II 62, 1, 1 - 7, 3; II, 63, 1, 1 - 3, 4.

${ }^{82}$ Por. tamże II 64, 1, 1 - 2, 7; II 67, 1, 1 - 2, 5; II 69, 1, 1 - 12, 3.

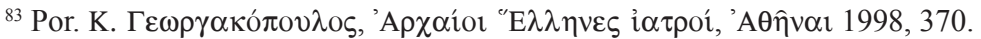

${ }^{84}$ Ksenokrates - grecki lekarz i farmakolog działający w drugiej połowie I w. po Chr., zwolennik stosowania kontrowersyjnych remediów pochodzących z ludzkich organizmów (niektórych narządów, wydzielin), krytykowany za to przez Galena. Autor kilku dzieł. Orybazjusz korzystał z dwóch jego prac: jednej, poświęconej użytecznym rzeczom pochodzącym z żyjących organizmów i drugiej, właśnie w tym miejscu, poświęconej stworzeniom morskim. Na temat Ksenokratesa zob. F. Kudlien, Xenokrates (8), RE IX/2 (2. Reihe) 1529-1531.

${ }^{85}$ Niewiele można powiedzieć o tym greckim lekarzu poza tym, że działał w okresie hellenistycznym. Por. K. Deichgräber, Mnesitheos (4), RE XV/2 2284; Kokoszko, Ryby i ich znaczenie, s. 19.

${ }^{86}$ Filotimos (prawdopodobnie III w. przed Chr.) - grecki lekarz z epoki wczesnohellenistycznej, którego dzieła znamy tylko dzięki późniejszym, cytującym je autorom antycznym. Napisał m.in. pracę dotyczącą jedzenia, w której omówił prawdopodobnie właściwości różnego rodzaju pokarmów, poświęcając każdą księgę innej ich grupie. Por. H. Diller, Phylotimos, RE XV/1 10301032; Kokoszko, Ryby i ich znaczenie, s. 18.

${ }^{87}$ Por. Oribasius, Collectiones medicae III 1, 1, 1 - 18, 2; III 2, 1, 1 - 26, 2; III 3, 1, 1 - 7, 3. 
powodującego powstawanie różnych rodzajów soków trawiennych ${ }^{88}$, znacznej ilości kału ${ }^{89}$, ponadto takiego, które jest zdrowe ${ }^{90}$, niezdrowe ${ }^{91}$, szkodliwe dla żołądka ${ }^{92}$, które źle wpływa na głowę ${ }^{93}$, powoduje wzdęcia ${ }^{94}$, bądź nie ${ }^{95}$, które przeczyszcza $^{96}$, bądź blokuje ${ }^{97}$ układ trawienny. Rozważania kończy omówienie pokarmów rozgrzewających ${ }^{98}$, chłodzących $^{99}$, wysuszających ${ }^{100}$ i zwilżających $^{101}$. Oparciem dla Orybazjusza przy tworzeniu trzeciej księgi był, jak możemy wnioskować na podstawie porównań, przede wszystkim Galen i jego dwa traktaty: De alimentorum facultatibus oraz De victu attenuante.

Księgę czwartą, liczącą zaledwie jedenaście paragrafów, poświęcił Pergamończyk różnym metodom przygotowania jedzenia, $w$ tym chleba ${ }^{102}$, kaszy ${ }^{103}$ i skrobi ${ }^{104}$, oraz pożywienia dla przewlekle chorych ${ }^{105}$. Wykorzystał przy tym dzieła różnych autorów. Obok wypisów z pism Galena (głównie różnych fragmentów pochodzących z jego najważniejszego źródła, De alimentorum facultatibus), zawarł tutaj informacje zaczerpnięte od Rufusa z Efezu, Mnesiteosa, Dieuchesa $^{106}$, Filotyma, Antylla ${ }^{107}$ i Dioklesa z Karystos ${ }^{108}$.

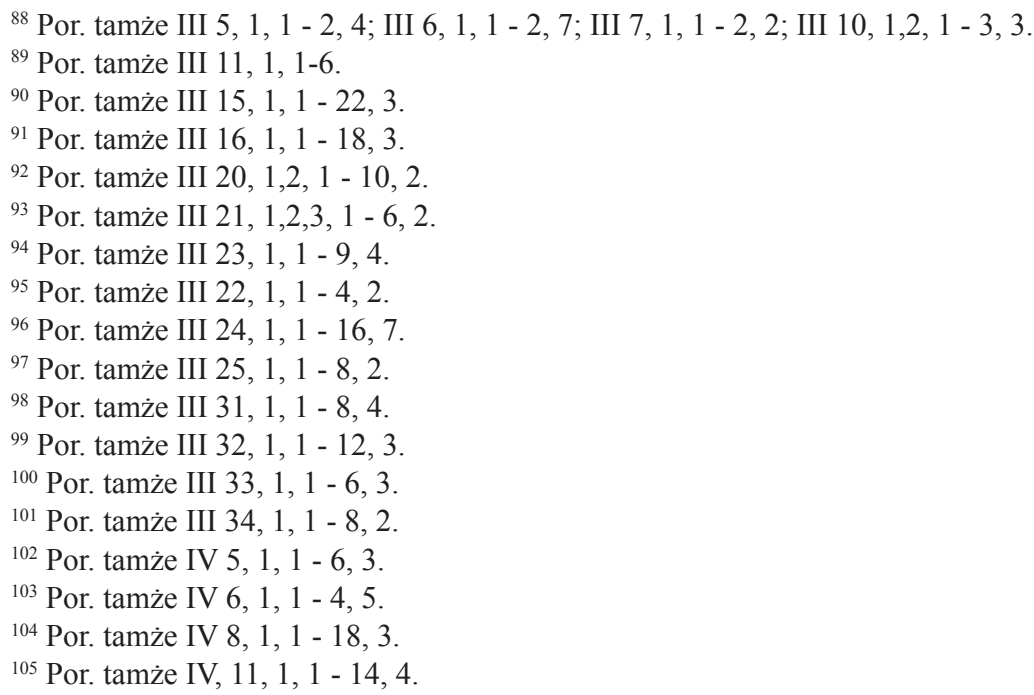

${ }^{106}$ Dieuches - grecki lekarz żyjący prawdopodobnie na początku III w. przed Chr. i należący do szkoły dogmatycznej. Autor m.in. dzieła poświęconego dietetyce, zachowanego tylko we fragmentach u innych autorów. Orybazjusz, prócz przywołanych w tym miejscu tekstu głównego naszego artykułu, powoływał się także gdzie indziej na jego opinie dotyczące choroby morskiej. Dieuches uznawał ciepło, zimno, wilgotność i suchość za podstawowe składniki ludzkiego ciała. Por. M. Wellmann, Dieuches (3), RE V 480.

${ }^{107}$ Antyllos (ok. pierwszej poł. II w. po Chr.) był greckim lekarzem, któremu przypisuje się przynależność do szkoły pneumatyków. Zachowane fragmenty jego pism dotyczą zarówno diety w antycznym, szerokim znaczeniu tego słowa, jak i chirurgii. Por. A.M. Ieraci Bio, Antyllos, AML 62-63.

${ }^{108}$ Diokles z Karystos (koniec IV w. przed Chr.) był cieszącym się wielką estymą medykiem greckim, określanym czasem jako „drugi Hipokrates”. Swymi rozległymi zainteresowaniami objął rozliczne gałęzie medycyny, co stawia go w wyjątkowym świetle na tle innych współczesnych mu lekarzy. Uchodzi również za zdolnego innowatora, przypisuje się mu bowiem zbudowanie przy- 
W piątej księdze Orybazjusz zawarł informacje dotyczące najważniejszych napojów obecnych w życiu mieszkańców Sródziemnomorza. Opisał różne rodzaje wody ${ }^{109}$, ocet winny zwany też fuską ${ }^{110} \mathrm{i}$ będący popularnym napojem w czasach antycznych, płyny oparte na miodzie ${ }^{111} \mathrm{i}$ jego mieszaniny $\mathrm{z}$ mlekiem ${ }^{112}$, wodą $^{113}$, oraz octem ${ }^{114}$, by najwięcej miejsca poświęcić rozmaitym rodzajom win i napitków mających za swą podstawę wina (między innymi trunkom doprawionym różami ${ }^{115}$, mirtem ${ }^{116}$, piołunem ${ }^{117}$, sokiem z powo$\mathrm{ju}^{118}$, tymiankiem ${ }^{119}$, wreszcie miodem i fiołkami ${ }^{120}$ ). Materiały wykorzystane w opisywanej księdze zebrał Orybazjusz korzystając z dzieł Galena, Rufusa z Efezu, Dioklesa z Karystos, Atenajosa z Attalii, Dioskuridesa ${ }^{121}$, Filagrio-

rządu do wydobywania strzał z ran. Wobec faktu, że jego dzieła znamy wyłącznie z przytoczonych przez późniejszych pisarzy fragmentów, ustalenie Dioklesowych poglądów może sprawiać trudności. Duże znaczenie przypisywał pneumie, Galen uważał go za zwolennika Hipokratesa i teorii czterech humorów. W zakresie dietetyki Karystejczyk zalecał dostosowywanie rodzaju pożywienia do pór roku, przypisując im określone jakości, takie jak ciepło-suchość i zimno-wilgoć. Zalecał również dopasowywanie pokarmu do stopnia zaawansowania ludzkiego wieku i do poziomu aktywności fizycznej. W swym rozległym dziele dotyczącym dietetyki zawarł szczegółowe opinie o zdrowym sposobie życia, pielęgnacji ciała, dobrym śnie i właściwym zrównoważeniu składników codziennej diety. Diokles był również doskonałym botanikiem i znamienitym przedstawicielem farmaceutyki, który jako jeden z pierwszych opisał działanie roślin na ludzki organizm, ponadto anatomem i ginekologiem. Por. M. Wellmann, Diokles (53), RE V 802-812; W. Jaeger, Diokles von Karystos, Berlin 1938, passim; K.H. Leven, Diokles v. Karystos, AML 225-227; Bednarczyk, Medycyna i filozofia w starożytności, s. 232-233, nota 11; Kokoszko, Ryby i ich znaczenie, s. 17; V. Nutton, Ancient Medicine, New York 2007, 120-123.

${ }^{109}$ Por. Oribasius, Collectiones medicae V 1, 1, 1 - 23, 23; V 2, 1, 1 - 10, 10; V 3, 1, 1 - 37, 6; $\mathrm{V} 4,1,1-2,3$.

${ }^{110}$ Por. tamże V 10, 1, 1-3; V 11, 1, 1 - 4, 2.

${ }^{111}$ Por. tamże V 15, 1, 1 - 3, 6; V 17, 1, 1 - 11, 4.

${ }_{112}$ Por. tamże V 14, 1, $1-7,5$.

${ }^{113}$ Por. tamże V 16, 1, 1 - 2, 5; V 25, 19, 1 - 20, 2; V 25, 21, 1-5.

${ }^{114}$ Por. tamże V 24, $1,1-15,3$.

${ }^{115}$ Por. tamże V 25, 25, 1 - 26, 2; V 33, 2, 1-4.

${ }_{116}$ Por. tamże V 25, 28, 1 - 30, 1 .

${ }^{117}$ Por. tamże V 25, 39, 1 - 40, 4.

${ }^{118}$ Por. tamże V 25, 44, 1 - 45, 2.

${ }^{119}$ Por. tamże V 25, 46, 1 - 47, 3.

${ }^{120}$ Por. tamże V 33, 6, 1-4.

${ }^{121}$ Pedaniusz Dioskurides (I w. po Chr.) był greckim farmakologiem, autorem wyśmienitej pracy znanej pod łacińskim tytułem De materia medica, w której część poświęcona ziołolecznictwu zyskała znakomitą opinię. Próbował w niej opisać w sposób systematyczny, co mu się nie zawsze udawało, rośliny znane w świecie greckim i ich medyczne zastosowanie. Jego herbarium wywarło ogromny wpływ na naukę, wypierając wcześniejsze zielniki i utrzymując swoją pozycję w Europie aż do wczesnej epoki nowożytnej, a na Wschodzie do XIX stulecia. Charakterystyczną cechą Dioskuridesa jako autora było skupienie się na merytorycznej, a nie stylistycznej stronie dzieła i oparcie się przede wszystkim na zebranych we własnym zakresie, w czasie licznych podróży, danych. W świetle naszych zainteresowań istotne jest, że Dioskurides zawarł w swym dziele również wiele informacji dotyczących różnych rodzajów pożywienia, w tym wina i innych napojów. Por. M. Wellmann, 
$\mathrm{sa}^{122}$, Antylla, Filotyma i Herodota ${ }^{123}$ - wybitnych starożytnych lekarzy i farmakologów.

Pozostałe księgi, których nie będziemy szczegółowo omawiać, traktują odpowiednio o: zdrowym sposobie życia, masażach, ćwiczeniach fizycznych, odpoczynku (ks. VI); o upuszczaniu krwi, stawianiu baniek, przystawianiu pijawek i przeczyszczeniach (ks. VII); o środkach przeczyszczających, lewatywach (ks. VIII); o warunkach zdrowotnych otoczenia człowieka i rodzajach okładów (ks. IX); o kąpielach i stosowaniu łaźni, oraz o zabiegach higienicznych, pigułkach i plastrach (ks. X); o rozmaitych prostych lekarstwach i środkach (ks. XI, XII, XIII, XIV i XV); o lekarstwach złożonych (ocalały fragment ks. XVI); o zewnętrznych i wewnętrznych narządach organizmu (ks. XXIV); o kościach, mięśniach i nerwach (ks. XXV); o wrzodach, żylakach, ropniach (fragment ks. XLIII); o wrzodach, przetokach i guzach (ks. XLIV); o obrzękach, torbielach, żylakach, tętniakach (ks. XLV); o złamaniach, zwichnięciach i stłuczeniach kości, a także o amputacjach (ks. XLVI i XLVII); o rodzajach bandaży i sposobach ich przygotowania (ks. XLVIII); o przemieszczeniach i zwichnięciach oraz o przyrządach stosowanych w ich leczeniu (ks. XLIX); o chorobach i zabiegach związanych z układem moczowym i płciowym (ks. L).

Z powyższego wykazu wynika, że do naszych czasów nie zachowały się znaczne partie Orybazjuszowego tekstu, to znaczy: większość księgi XXIV, cała zawartość siedemnastu ksiąg od XXVI do XLII, część księgi XLIII oraz materiał umieszczony w ostatnich dwudziestu (lub dwudziestu dwóch) księgach od LI do LXX (lub LXXII). Wprawdzie nie jesteśmy w stanie stwierdzić, jak Pergamończyk rozplanował swe dzieło, a tym samym jak rozległe były utracone fragmenty Collectiones medicae (dla porówniania zachowane po dziś dzień księgi znacznie różnią się od siebie długością), ale wydaje się, że stwierdzenie o zaginięciu, w przybliżeniu, jego połowy, nie jest nazbyt śmiałą konstatacją.

Pisząc powyższe księgi, Orybazjusz, podobnie jak w przypadku pierwszych pięciu, posługiwał się zgromadzonymi przez siebie materiałami, ukła-

Dioskurides (12), RE V 1131-1142; C. Singer, The Herbal in Antiquity, „The Journal of Hellenic Studies" 47 (1927) 1-31; Scarborough, Early Byzantine Pharmacology, s. 221; M. Stamatu, Dioskurides, AML 227-229; Kokoszko, Ryby i ich znaczenie, s. 12.

${ }^{122}$ Przywołany autor był greckim lekarzem działającym najpewniej w 1. poł. IV w. po Chr. (a więc niedługo przed samym Orybazjuszem). Napisał ponad 70 traktatów medycznych, podręczników i komentarzy do pism Hipokratesa, z których tylko fragmenty dotrwały do naszych czasów. Był autorytetem w dziedzinie chorób wątroby i śledziony, ale w swoich pismach podejmował tematykę lekarską w znacznie szerszym zakresie (choroby kobiece, choroby układu moczowego, pewne zagadnienia chirurgiczne, głuchota, cukrzyca). Jego twórczość oddziaływała na myśl medyczną Bizancjum, Zachodu i, przede wszystkim, Arabów. Por. E. Bernert, Philagrios (2), RE XIX/2 2103 2105; R. Masullo, Philagrios, AML 693-694.

${ }^{123}$ Nie chodzi tu jednak o „ojca historii”, lecz lekarza, przedstawiciela szkoły pneumatycznej, działającego w 2. poł. I w. po Chr., autora kilku pism, traktujących m.in. o gorączkach i towarzyszących im problemach ze snem, o zaburzeniach apetytu, różnych rodzajach opatrunków, nacieraniu ciała etc. Por. H. Gossen, Herodotos (12), RE VIII 990-991. 
dając potrzebne mu partie tekstu napisanego przez wcześniejszych autorów w pożądaną przez siebie całość.

Nie posiadamy żadnych informacji dotyczących oddźwięku, z jakim spotkały się Collectiones medicae wśród potencjalnych czytelników jeszcze za życia swojego autora. Fakt, że były one cytowane wiele stuleci po swym powstaniu, czym szerzej zajmiemy się później, może dawać pewne podstawy przypuszczeniu, że i w IV wieku znalazły wśród ludzi zainteresowanych medycyną grono uważnych i żywo reagujących na nie czytelników.

Swego rodzaju świadectwem potwierdzającym to może być również fakt, że kilka dziesięcioleci później Orybazjusz zdecydował się na stworzenie nowego dzieła. Miało ono być z jednej strony oparte na Collectiones medicae, z drugiej jednak - stanowić poważny skrót wiadomości zawartych w swym pierwowzorze. Przypuszczalnie tworząc to nowe pismo, które zatytułował $S y$ nopsis ad Eustathium filium (dedykując je swemu synowi Eustacjuszowi, który również uczył się medycyny), Pergamończyk zareagował na dochodzące doń opinie na temat swego opus magnum, które zapewne z jednej strony pełne były uznania, z drugiej musiały zawierać w sobie ziarno krytyki. Dotyczyła ona przypuszczalnie m.in. zbyt dużych rozmiarów dzieła, co z pewnością utrudniało sprawne i szybkie posługiwanie się nim, zwłaszcza początkującym czytelnikom. Niewątpliwym ukłonem właśnie w stronę grupy odbiorców obeznanych wprawdzie z naukami medycznymi, lecz niezadowolonych z konieczności wertowania dużej ilości woluminów było znaczne skrócenie pewnych partii materiału, mogące niekiedy wręcz prowadzić do nieporozumień i błędnych decyzji dotyczących wyboru właściwej metody leczenia pacjen$\operatorname{ta}^{124}$. Niektóre zagadnienia, również ze względów praktycznych, Orybazjusz w ogóle usunął. Efektem podjętej na nowo pracy pisarskiej było liczące dziewięć ksiąg dzieło ${ }^{125}$. Spośród nich wszystkich więcej miejsca poświęcimy pre-

${ }^{124}$ Pozwolimy sobie nieśmiało zasugerować, że pewnym świadectwem problemów, jakie sprawiały czytelnikom Collectiones medicae, może być sposób, w jaki wszystkie dzieła Orybazjusza potraktował podczas ich omawiania Focjusz, który nieproporcjonalnie dużo miejsca poświęcił w swej Bibliotece (cod. 218) mniejszym pismom Pergamończyka, a o Collectiones wypowiedział się bardzo ogólnikowo. Sprawia to wrażenie, że nie miał dość czasu, by głębiej wniknąć w zawarty tam materiał. Również od Focjusza dowiadujemy się o możliwych problemach, jakie lektura Synopsis sprawiała ludziom niedoświadczonym w leczeniu i błędach, jakie niosła zła interpretacja jej treści.

${ }^{125}$ Informacje na temat Synopsis ad Eustathium flium zob. M. Neuburger, Geschichte der Medizin, Stuttgart 1911, 49 i 52; Schröder, Oreibasios, kol. 802-803; De Lucia, Doxographical Hints, s. 473 i 475. Data powstania tego dzieła, wprawdzie nieznana, może być w przybliżeniu określona na rok 390. Podstawą dla takiego datowania jest znajomość burzliwych kolei losu Orybazjusza, który dopiero w średnim wieku ożenił się i doczekał potomstwa. W związku z tym, jak przypuszczamy, jego syn Eustacjusz nie mógł studiować medycyny przed tą umowną datą, ponieważ był na to za młody. Jednym z najważniejszych zagadnień medycznych pominiętych tu przez Orybazjusza jest chirurgia. Przyczyną tego braku jest jedno z przeznaczeń Synopsis - autor wyobrażał ją sobie jako dzieło, z którego z powodzeniem można korzystać w podróży, gdzie stosowanie przyrządów chirurgicznych było utrudnione. 
zentacji treści jedynie tej, która związana jest z zagadnieniami dietetycznymi, tj. księgi czwartej.

Składają się na nią informacje dotyczące właściwości jedzenia i jego wpływu na ludzki organizm: odchudzania ${ }^{126}$, tuczenia ${ }^{127}$, pobudzania do produkcji różnych wydzielin ${ }^{128}$, wywoływania niestrawności ${ }^{129}$, szkodliwości dla żołądka ${ }^{130}$, powodowania wzdęć ${ }^{131}$, przeczyszczania ${ }^{132}$, czy wreszcie ogrzewania $^{133}$ i ochładzania ${ }^{134}$. Następnie w kilku ostatnich rozdziałach autor opisuje mleko $^{135}$ i mleko z miodem ${ }^{136}$, napoje dobre dla chorych $^{137}$, przygotowanie papek $^{138}$ oraz wodę ${ }^{139}$.

Pozostałe księgi omawianego dzieła zawierały informacje dotyczące: gimnastyki, stosunków seksualnych i upuszczania krwi (ks. I), właściwości i przygotowania leków (ks. II i III), dietetyki w okresie ciąży, a także poszczególnych okresach życia i wykonywanych zawodów (ks. V), zagadnienień związanych z kryzysem w chorobie, uroskopii, gorączek, (ks. VI), ran, obrzęków i wrzodów (ks. VII), chorób umysłowych, chorób nosa, oczu, warg (ks. VIII), problemów z narządami wewnętrznymi (wątrobą, nerkami, jelitami itd.) oraz chorób kobiecych (ks. IX).

Niedługo po stworzeniu dzieła dedykowanego synowi, Orybazjusz zabrał się za pisanie kolejnej pracy, której przedmiotem miała być medycyna. Oto na prośbę swego przyjaciela, Eunapiusza ${ }^{140}$, podjął się trudu uprzystępnienia osiągnięć sztuki lekarskiej zainteresowanym nią, wykształconym laikom, którzy zamierzali wykorzystywać opanowaną w ten sposób wiedzę dla własnych potrzeb: rozpoznania u siebie niepokojących objawów chorobowych, zareagowania na atak choroby w czasie podróży, czy w sytuacji braku możliwości skorzystania z usług zawodowego medyka. Według Pergamończyka, czytelnicy mogli również, po uważnej lekturze dzieła, podjąć decyzję o kierunku leczenia w przypadku rozbieżności opinii wyrażanych przez sprowadzonych na miejsce profesjonalnych lekarzy. Powstałe dzieło, znane jako Libri ad Eu-

${ }^{126}$ Por. Oribasius, Synopsis ad Eustathium filium IV, 1, 1 - 22, 3.

${ }^{127}$ Por. tamże IV 2, 1 - 5, 3.

${ }^{128}$ Por. tamże IV 4, 1, 1 - 3, 4; IV 5, 1, 1 - 2, 7; IV 6, 1, 1 - 2, 2; IV 7, 1, 1-4; IV 8, 1, 1 - 2, 5; IV 9, 1,2, $1-3,3$.

${ }^{129}$ Por. tamże IV 17, 1, $1-12,1$.

${ }^{130}$ Por. tamże IV 19, 1, $1-10,2$.

${ }^{131}$ Por. tamże IV 22, 1, $1-10,1$.

${ }^{132}$ Por. tamże IV 23, 1, $1-16,7$.

${ }^{133}$ Por. tamże IV 31, 1, 1 - 8, 4.

${ }^{134}$ Por. tamże IV 32, 1, 1 - 13, 2.

${ }^{135}$ Por. tamże IV 40, 1, 1 - 6, 3.

${ }^{136}$ Por. tamże IV 38, 1, 1 - 5, 2.

${ }^{137}$ Por. tamże IV 39, 1, 1 - 8, 3.

${ }^{138}$ Por. tamże IV 35, 1, 1 - 19, 3.

${ }^{139}$ Por. tamże IV 41, 1, 1 - 13, 5.

${ }^{140}$ Chodzi najpewniej o Eunapiusza z Sardes (ur. ok. 346 - zm. po 404), Orybazjuszowego przyjaciela i biografa. Por. W. Schmid, Eunapios, RE VI 1121-1124; Schröder, Oreibasios, kol. 803. 
napium, liczyło cztery księgi. Dietetyka zajmuje w nim obszerne fragmenty pierwszej z nich ${ }^{141}$.

W księdze tej mowa jest między innymi o jedzeniu dostosowanym do wieku człowieka: dla dziecka ${ }^{142}$, człowieka dojrzałego ${ }^{143}$ i starca ${ }^{144}$, a także o mocy wina $^{145}$, właściwościach pokarmów (w tym: tuczeniu ${ }^{146} \mathrm{i}$ odchudzaniu ${ }^{147}$, pobudzaniu do produkcji różnych wydzielin przez organizm ${ }^{148}$, pożywności ${ }^{149}$, strawności ${ }^{150}$, rozdymaniu ${ }^{151}$, przeczyszczaniu ${ }^{152}$, rozgrzewaniu ${ }^{153}$, ochładzaniu ${ }^{154}$, nawilżaniu $^{155}$ i wysuszaniu ${ }^{156}$ ) oraz o wpływie jedzenia na stan uzębienia ${ }^{157}$.

Pozostałe fragmenty księgi I poświęcone są higienie. W kolejnych partiach pracy Pergamończyk zajął się właściwościami, działaniem i wskazanymi zastosowaniami leków (ks. II i III) oraz opisem poszczególnych części ciała i ich chorób, wraz z lekami na nie (ks. IV). Warto zauważyć, że Libri ad Eunapium, choć zawierało podobne elementy i przypominało treścią wcześniejsze prace Orybazjusza, nie było jedynie streszczeniem wcześniejszego skrótu, o czym najlepiej świadczą niektóre passusy omawianego tu dzieła, w których podejmuje pewne kwestie w sposób inny, bardziej rozbudowany, niż w Synopsis ad Eustathium filium ${ }^{158}$.

Możliwe, że scharakteryzowane powyżej cztery dzieła o tematyce medycznej, nie były jedynymi, w których zajmował się nią Orybazjusz. Ze wzmianek Focjusza dowiadujemy się, że istniało jeszcze siedem innych dzieł Pergamończyka, posiadających podobną formę, których już duchowny najwyraźniej nie przeczytał ${ }^{159}$. Dziś nie możemy powiedzieć na ich temat nic ponad to, że zostały w tym miejscu wspomniane. Nie wiadomo, jakie

${ }^{141}$ Informacje na temat omawianego dzieła zob. Neuburger, Geschichte der Medizin, s. 53; Schröder, Oreibasios, kol. 803; De Lucia, Doxographical Hints, s. 473.

${ }_{142}$ Por. Oribasius, Libri ad Eunapium I 1, 1, 1 - 9, 3.

${ }^{143}$ Por. tamże I 2, 1, $1-8,11$.

${ }^{144}$ Por. tamże I 11, 1, 1 - 19, 3.

${ }^{145}$ Por. tamże I 12, 1, 1 - 6, 3.

${ }^{146}$ Por. tamże I 19, 1, 1 - 5, 4.

${ }^{147}$ Por. tamże I 18, 1, 1 - 18, 2.

${ }^{148}$ Por. tamże I 21, 1, 1 - 3, 3; I 22, 1,2, 1 - 2, 8; I 23, 1, 1-3; I 24, 1, 1-4; I 25, 1, 1 - 2, 4; I 26,

$1,2,1-3,3$.

${ }^{149}$ Por. tamże I 29, 1, 1 - 15, 2; I 30, 1, 1 - 8, 2; I 31, 1,2, 1 - 2, 3.

${ }^{150}$ Por. tamże I 34, 1, 1 - 11, 2; I 35, 1, 1 - 8, 2; I 36, 1, 1 - 6, 3; I 43, 1,2, 1 - 3, 4; I 44, 1, 1 - 2, 3.

${ }^{151}$ Por. tamże I 38, 1, 1 - 3, 1; I 39, 1, 1 - 7, 1.

${ }^{152}$ Por. tamże I 40, 1, 1 - 14, 7.

${ }^{153}$ Por. tamże I 47, 1, 1-9.

${ }^{154}$ Por. tamże I 48, 1, 1 - 7, 3.

${ }^{155}$ Por. tamże I 50, 1, 1 - 4, 2.

${ }^{156}$ Por. tamże I 49, 1, 1 - 3, 4.

${ }^{157}$ Por. tamże I 52, 1, 1-5.

${ }^{158}$ Por. De Lucia, Doxographical Hints, s. 475. Autor wspomina, że w Libri ad Eunapium Orybazjusz pozwalał sobie na więcej teoretyzowania niż we wcześniejszym Synopsis.

${ }^{159}$ Por. Photius, Bibliotheca cod. 216. 
nosiły tytuły, czego dotyczyły, ani nawet, czy były oryginalnymi pracami Orybazjusza, czy też jedynie krążącymi po bizantyńskim świecie, mniej lub bardziej wiernymi kopiami jego pism, tylko przez pomyłkę branymi za odrębne dzieła ${ }^{160}$.

Ramy niniejszego artykułu nie pozwalają, niestety, na obszerniejsze zaprezentowanie treści innych, niż dietetyczne, ksiąg składających się na lekarskie dzieła Orybazjusza, w których znalazło się miejsce dla opisów wielu dolegliwości znanych wcześniejszym autorom starożytnym a i dziś dotykających dużą część populacji, wobec czego poglądy antyczne na ich przyczyny i leczenie wydają się być szczególnie interesujące. Z zachowanych części Orybazjuszowych traktatów wyczytać można informacje o takich spośród nich, jak: cukrzyca $^{161}$, chorobliwa otyłość ${ }^{162}$, kamica nerkowa ${ }^{163}$, rak $^{164}$, choroby oczu ${ }^{165}$ oraz o pewnych metodach terapeutycznych, jak ćwiczenia lecznicze ${ }^{166}$, zabiegi kosmetyczne ${ }^{167}$, laryngologiczne ${ }^{168}$, urologiczne ${ }^{169}$, leczenie żylaków ${ }^{170}$,

${ }^{160}$ Podobny przypadek opisuje sam Focjusz (Bibliotheca cod. 219), gdy wspomina o nieznanym, zagadkowym dziele Orybazjusza zadedykowanym niejakiemu Eugeniuszowi, które przypominało w pewnym stopniu pismo napisane dla Eunapiusza, jednak w wielu miejscach od niego odbiegało. Mogło być zatem bardzo niedokładną kopią, zupełnie innym dziełem, bądź fałszerstwem anonimowego autora chcącego podnieść rangę swego tworu imieniem uznanego autorytetu, jakim niewątpliwie był Orybazjusz.

${ }^{161}$ Por. H. Christopoulou-Aletra - N. Papavramidou, „Diabetes” as Described by Byzantine Writers From the Fourth to the Ninth Century AD: the Graeco-Roman Influence, „Diabetologia” 51 (2008) 892-896.

162 Por. N. Papavramidou - H. Christopoulou-Aletra, Greco-Roman and Byzantine Views on Obesity, „Obesity Surgery” 17 (2007) 112-116.

${ }^{163}$ Por. J. Lascartos - G. Lascartos - A. Kostakopoulos, Surgical Confrontation of Urolithiasis in Byzantium, „Urology” 63 (2004) nr 4, 806; N. Pardalidis - C. Tsiamis - A. Diamantis - N. Andriopoulos - N. Sofikitis, Methods of Lithotripsy in Ancient Greece and Byzantium, „The Journal of Urology" 178 (2007) 1182-1183.

${ }^{164}$ Por. A. Karpozilos - N. Pavlidis, The Treatment of Cancer in Greek Antiquity, „European Journal of Cancer" 40 (2004) 2033-2040.

${ }^{165}$ D. Brouzas - A. Charakidas - M. Vasilakis - P. Nikakis - D. Chatzoulis, Nyctalopia in Antiquity. A Review of the Ancient Greek, Latin, and Byzantine Literature, „Ophthalmology” 108 (2001) 1919.

${ }^{166}$ Na temat użycia piłek zob. W.B. McDaniel, Some Passages Concerning Ball-Games, „Transactions and Proceedings of the American Philological Association" 37 (1906) 121-134.

${ }^{167}$ Por. J. Lascaratos - C. Tsiamis - G. Lascaratos - N.G. Stavrianeas, The Roots of Cosmetic Medicine: Hair Cosmetics in Byzantine Times (AD 324-1453), „Internatonal Journal of Dermatology" 43 (2004) 397.

${ }^{168}$ Por. J. Lascaratos - D. Assimakopoulos, Surgery on the Larynx and Pharynx in Byzantium (AD 324-1453): Early Scientific Descriptions of These Operations, „Otolaryngology - Head and Neck Surgery” 122 (2000) nr 4, 579-583.

${ }^{169}$ Por. J. Lascartos - A. Kostakopoulos - E. Liapi - G. Lascartos, Unknown Methods of Uncircumcision According to Oribasius (4th Century A.D.), „Urology” 62 (2003) nr 1, 193-196.

${ }^{170}$ Por. J. Lascaratos - C. Liapis - M. Kouvaraki, Surgery on Varices in Byzantine Times (3241453 CE), „Journal of Vascular Surgery” 33 (2001) nr 1, 197-203. 
cewnikowanie ${ }^{171}$, których omówienie w przedstawionych dziełach jedynie sygnalizujemy.

Poświęcone medycynie pisma Orybazjusza (był też autorem przynajmniej jednego dzieła o charakterze pamiętnikarskim, nieistotnego dla naszych obecnych rozważań) miały duży wpływ na kolejne pokolenia lekarzy bizantyńskich, arabskich i zachodnioeuropejskich. Nie ulega wątpliwości, że korzystali z nich kolejni wybitni kompilatorzy piszący po grecku, dla których Orybazjuszowe piśmiennictwo stanowiło wzór do naśladowania i kopalnię gotowych formuł: Aecjusz z Amidy (ok. VI/VII w.) przy tworzeniu liczącej szesnaście ksiąg pracy omawiającej sztukę lekarską ${ }^{172}$, Aleksander z Tralles W swej dwunastotomowej księdze poświęconej medycynie ${ }^{173}$, a także Paweł z Eginy (VII w.) pisząc każdy z siedmiu woluminów swego dzieła ${ }^{174}$. O późniejszym korzystaniu przez świat bizantyński z pozostawionych przez Pergamończyka kompilacji świadczą również słowa wielokrotnie przywoływanego powyżej patriarchy Focjusza, który znał Orybazjuszową spuściznę i uważał ją za godną polecenia, przy czym szczególnie cenne były dlań Collectiones medicae, jako najpełniejsze i opisujące temat w sposób najbardziej wyczerpujący ${ }^{175}$.

Po podboju ogromnych obszarów należących do Cesarstwa Bizantyńskiego w VII w., z osiągnięciami greckiej medycyny zapoznali się Arabowie. Terenem szczególnie intensywnie uczestniczącym w przyswajaniu przez zdobywców nowej dla nich wiedzy była Syria, język bowiem syryjski, zdecydowanie bardziej niż grecki zbliżony do arabskiego, doczekał się już wcześniej thumaczeń helleńskiej literatury (jednym z czołowych translatorów był działający w VI stuleciu Sergiusz z Reshainy, bądź według innej wersji Sarğis z Rīs ainā, ale prekursorzy tej działalności pracowali już kilka stuleci wcześniej) i uła-

${ }^{171}$ Por. F.P. Moog - A. Karenberg - F. Moll, The Catheter and Its Use in Late Antiquity and the Early Middle Ages, „The Journal of Urology” 174 (2005) 439.

${ }^{172}$ Por. informacje na temat zależności Aecjusza od Orybazjusza: M. Wellmann, Aetios (8), RE I 703; Neuburger, Geschichte der Medizin, s. 105; Schröder, Oreibasios, kol. 811; Scarborough, Early Byzantine Pharmacology, s. 235; N.G. Wilson, Scholars of Byzantium, London 1996, 57; A. Garzya, Aetios v. Amida, AML 20. Zob. również artykuł, w którym Alexander Sideras [Aetius und Oribasius. Ihre gemeinsamen Exzerpte aus der Schrift des Rufus von Ephesos „Über die Nieren- und Blasenleiden" und ihr Abhängigkeitsverhältnis, ByZ 67 (1974) 110-130] wykazuje pewną niezależność Aecjusza od Orybazjusza w cytowaniu pisma Rufusa z Efezu poświęconego chorobom nerek i pęcherza.

${ }^{173}$ Chociaż podkreśla się dużą samodzielność Aleksandra, co odróżnia go od bizantyńskich kompilatorów, korzystał on również z dorobku wcześniejszych pokoleń, w tym autora Collectiones medicae. Por. Schröder, Oreibasios, kol. 810.

${ }^{174}$ Paweł z Eginy jest szczególnie mocno zależny od Orybazjusza, przy czym - co ciekawe - częściej opiera się na Synopsis ad Eusthatium filium niż na - jego zdaniem przydługich - Collectiones medicae (choć one również stanowią dlań niezmiernie ważne źródło. Na temat związków pomiędzy tekstem Pawła a Orybazjusza zob. Schröder, Oreibasios, kol. 810; H. Diller, Paulus (23), RE XVIII/4 2386-2397 (spec. 2389-2395); P. Pormann, Paulos v. Aigina, AML 681.

${ }^{175}$ Por. Photius, Bibliotheca cod. 217. 
twiał przybyszom zrozumienie oraz przekład oryginalnych tekstów jakie do nich trafiały ${ }^{176}$. Dzieła Orybazjusza były Syryjczykom znane, o czym świadczą pewne uwagi najwybitniejszego autora przekładów reprezentującego ten krąg kulturowy, Hunayna ibn Ishāq (IX w.) ${ }^{177}$. Dzięki niemu, jego uczniom i wielu innym tłumaczom świat arabski przyswoił sobie korpus greckich dzieł lekarskich. O tym, że poczesne miejsce zajmował wśród poznawanych autorów Orybazjusz, świadczą wzmianki o nim i o jego pismach pojawiające się u autorów takich jak al-Nadim (Muhammad ibn Is'hāq, X w.), który stworzył obszerne dzieło będące wykazem wszystkich prac, jakie napisano $\mathrm{w}$ języku $\operatorname{arabskim}^{178}$, ibn Samğūn (X/XI w.), ze swą encyklopedią poświeconą ziołolecznictwu ${ }^{179}$, al-Kifti (Djemal ud-Din, XII/XIII w.), lekarz i twórca biografii uczonych ${ }^{180}$ oraz historyk medycyny ibn abi Oseibia (XII/XIII w.) ${ }^{181}$. Ich znajomość dorobku Orybazjusza oraz epoki, w jakiej ten lekarz działał, była mocno niepełna i niedokładna, a jego największe dzieło, ze względu na swe olbrzymie rozmiary, pozostawało prawie nieznane. Tym niemniej owa znajomość pozostaje dla nas ważnym świadectwem znaczenia jego twórczości W świecie arabskim ${ }^{182}$.

${ }^{176} \mathrm{Na}$ temat roli języka syryjskiego w otwarciu się Arabów na medyczny dorobek Greków oraz ówczesnych technik translatorskich na tym obszarze zob. S. Brock, Greek Into Syriac and Syriac Into Greek, w: tenże, Syriac Perspectives on Late Antiquity, London 1984, 1-17; tenże, Aspects of Tanslation Technique in Antiquity, w: Syriac Perspectives, s. 69-87; N.W. Pigulewska, Kultura syryjska we wczesnym średniowieczu, tłum. C. Mazur, Warszawa 1989, 169nn.

${ }^{177} \mathrm{Na}$ temat roli Hunayna zob. S. Hamarneh, Medical Education and Practice in Medieval Islam, w: The History of Medical Education, ed. C.D. O'Malley, Berkeley - Los Angeles - London 1970, 45-48; M. Ullmann, Islamic Medicine, Edinburgh 1978, 9-10; Pigulewska, Kultura syryjska, s. 179-195; U. Weisser, Arabische Medizin, AML 74-75; K.H. Leven, Hunayn ibn Ishāq, AML 441. Syryjski tłumacz stwierdził przy okazji omawiania dorobku Galena, że już Orybazjusz nie mógł znaleźć jednej z przypisywanych swemu wielkiemu poprzednikowi prac. Zatem wnosić możemy, że Hunayn był zaznajomiony z dorobkiem Orybazjusza, skoro się nań powoływał, o ile nie uznamy że sam nie uczestniczył w thumaczeniach tegoż dorobku, jakie przypisywane są ogólnie jego najbliższemu otoczeniu. Por. np. Hamarneh, Medical Education, s. 48.

${ }^{178}$ Por. M. Steinschneider, Die arabischen Übersetzungen aus dem griechischen, Leipzig 1897, $8-10$.

179 Por. T. Fahd, Botanika i rolnictwo, w: Historia nauki arabskiej, t. 3: Technika, alchemia, nauki przyrodnicze i medycyna, tłum. J. Kozłowska - K. Pachniak, Warszawa 2005, 73.

${ }^{180}$ Por. A. Müller, Über das sogenannte خير ات عامك - des Ibn el-Quifti, w: Actes du huitième Congrès International des Orientalistes tenu en 1889 à Stockholm et à Christiania, Section I: Sémitique (A), 1 fasc., Leiden 1891, 19-33; Steinschneider, Die arabischen Übersetzungen, s. 10-11.

${ }^{181}$ Por. Steinschneider, Die arabischen Übersetzungen, s. 11-12.

182 Por. tamże, s. 476-477; Ullmann, Islamic Medicine, s. 13-15. Brak gruntownej wiedzy owych autorów na temat Orybazjusza ilustruje ich kłopot z podaniem tak podstawowej informacji dotyczącej go jak to, czy tworzył przed, czy po Galenie, lub uznawanie Eunapiusza za ojca autora Libri ad Eunapium. Z kolei trudności w opanowaniu jego dorobku ukazuje nieumiejętność podania prawidłowej listy jego dzieł i dołączanie do niej traktatów, których my dziś z nim nie wiążemy. Mimo to pisma Orybazjusza były dla Arabów ważnym źródłem informacji, szczególnie w miejscach, gdzie miały odniesienia do już niedostępnych dzieł wcześniejszych autorów. 
Trzecim wielkim kręgiem kulturowym, do którego dzieła Orybazjusza trafiły i w którym oddziaływały na sztukę medyczną, był łaciński Zachód Europy. W VI w. w okolicach Rawenny powstały dwa tłumaczenia pism Pergamończyka, przy czym zdecydowanie większy oddźwięk miało młodsze z nich, które kopiowano kilkakrotnie w ciągu kolejnych stuleci na obszarze Italii, Francji i Niemiec. Niemniej wpływ obu wspomnianych tłumaczeń był stosunkowo ograniczony i wydaje się, że dość rzadko korzystano z nich przy opracowywaniu kolejnych ksiąg poświęconych medycynie ${ }^{183}$. Znajomość Orybazjusza charakteryzowała również przedstawicieli kwitnącej między X a XIII stuleciem szkoły medycznej z południowoitalskiego Salerno, wsławionej między innymi thumaczeniami pism o tematyce medycznej z greki i arabskiego na łacinę, i związanej z tzw. dwunastowiecznym renesansem na terenie Sycylii i południu Półwyspu Apenińskiego ${ }^{184}$.

Idee przyjęte i rozbudowane przez Galena, utrwalone następnie przez Orybazjusza i zaakceptowane przez innych pisarzy bizantyńskich zajmujących się medycyną, tworzące swego rodzaju zbiór poglądów nazywany galenizmem, były przez długi czas uznawane za słuszne ${ }^{185}$, a głosy krytyki wobec nich pozostawały odosobnione ${ }^{186}$. Dopiero rozwój nauki w nowożytnej Europie Zachodniej spowodował, że około XVII stulecia zaczęto na dorobek późno-

${ }^{183}$ Por. G. Baader, Early Medieval Latin Adaptations of Byzantine Medicine in Western Europe, DOP 38 (1984) 252; tenże, Byzantinische Medizin in Norditalien im 5. und 6. Jahrhundert, w: From Late Antiquity to Early Byzantium. Proceedings of the Byzantinological Symposium in the 16th International Eirene Conference, ed. V. Vavř́nek, Praha 1985, 244. Na temat północnoitalskich, łacińskich tłumaczeń pism Orybazjusza zob. również H. Mørland, Die lateinischen Oribasiusübersetzungen, Osloae 1932, passim.

${ }^{184}$ Por. M.H. Green, Introduction, w: The Trotula. A Medieval Compendium of Women's Medicine, ed. M.H. Green, Philadelphia 2001 (=Trotula), 3-14. Zob. także K. Pachniak, Nauka i kultura muzutmańska i jej wptyw na średniowieczna Europę, Warszawa 2010, 127-129. W traktacie przypisywanym niekiedy mającej pochodzić z Salerno lekarce Trotuli (lub Trocie), Orybazjusz wymieniony jest z imienia przy okazji opisu histerii (czyli kobiecej przypadłości związanej według ówczesnych badaczy z ruchami macicy i powodującej m.in. trudności w oddychaniu, bóle, utratę głosu), por. Trotula 50, ed. Green, s. 85-86. Na temat starożytnego i bizantyńskiego spojrzenia na tę przypadłość zob. H. Merskey - S.J. Merskey, Hysteria, or „Suffocation of the Mother”, „Canadian Medical Association Journal” 148 (1993) nr 3, 399-401.

${ }^{185} \mathrm{Na}$ temat roli, jaką w powstaniu zjawiska galenizmu odegrał Orybazjusz zob. O. Temkin, Galenism. Rise and Decline of a Medical Philosophy, Ithaca - London 1974, 62-64.

${ }^{186}$ Por. K.H. Leven (Das Bild der byzantinischer Medizin in der Satire Timarion, „Gesnerus” 47 (1990) 247-262; Galenkritik, AML 321-322) informuje o nielicznych sprzeciwach wobec dominacji poglądów Galena w bizantyńskiej literaturze, wyrażonych, między innymi, przez Symeona Setha (XI w.) oraz anonimowego autora satyry zatytułowanej Timarion (ok. XII w.). Por. E. Konstantinou, Die byzantinische Medizin im Lichte der anonymen Satire ,, Timarion”, „Byzantina” 12 (1983) 159-181, gdzie mowa również o innych przykładach literackiego sprzeciwu wobec dominacji galenizmu. Rzeczywistą skalę tego zjawiska trudno ocenić ze względu na fakt, iż możemy się opierać na nielicznych źródłach, często o specyficznym, nie fachowym charakterze. Wydaje się jednak, że gdyby poglądy Galena i jego naśladowców były bardziej stanowczo poddawane w wątpliwość, to zjawisko takie pozostawiłoby po sobie wyraźniejszy ślad w piśmiennictwie. 
rzymskiej medycyny patrzeć z pogłębiającym się dystansem, by ostatecznie przestać na ów dorobek zważać przy stosowaniu medycyny w praktyce ${ }^{187}$.

Z dzisiejszego punktu widzenia pisma Orybazjusza przedstawiają dla nas dużą wartość z dwóch powodów. Po pierwsze, ukazują późnorzymski/wczesnobizantyński stan wiedzy medycznej, stosowane metody leczenia, rozpoznawane choroby i sposoby określania ich przyczyn. Po drugie, stanowią skarbnicę informacji o dziełach starożytnych autorów, których w wielu przypadkach znamy tylko dzięki Orybazjuszowym cytatom. Pergamończyk miał bowiem w zwyczaju informować, skąd czerpie podawane przez siebie wiadomości. Niekiedy czynił to jedynie ogólnie, wymieniając tylko imię cytowanego autora, czasem natomiast wskazywał na konkretny fragment dzieła, z jakiego korzystał. Porównanie jego zapożyczeń z materiałem pochodzącym bezpośrednio z pism przytaczanych przez niego autorów dobitnie wskazuje, że Orybazjusz najczęściej cytował swe źródła dosłownie, z niewielkimi zmianami polegającymi na zastosowaniu innego szyku wyrazów, bądź łączeniu w jeden rozdział kilku fragmentów rozrzuconych w kilku miejscach cytowanej pracy. Pozwala to żywić opartą na solidnych podstawach nadzieję, że również w tych fragmentach, w których powoływał się na pisarzy dla nas zaginionych, czynił to równie wiernie. Daje nam to powody, by uznać, że czytając takie fragmenty, obcujemy w istocie nie tyle z tekstem Orybazjusza, lecz z jego, niedostępnymi współcześnie, często wiele wieków starszymi, źródłami ${ }^{188}$.

W kontekście niniejszego artykułu ważne jest jednak, że Pergamończyk był nie tylko bezrefleksyjnym kompilatorem, ale zaczerpnięte skądinąd informacje uzupełniał niekiedy, lub modyfikował, według swojego uznania. Dotyczyło to również fragmentów poświęconych właściwościom pokarmów. Można więc, jak sądzimy, założyć, że zawarte w jego pismach wiadomości na temat pożywienia, bez względu na to, czy są dosłownymi cytatami wcześniejszych autorów, czy też poddane zostały modyfikacjom, odzwierciedlają w niemałym stopniu dietetyczne zachowania współczesnych Orybazjuszowi mieszkańców państwa rzymskiego.

${ }^{187}$ Nie znaczy to, że całość wiedzy zawartej w dziełach medycznych antycznych i bizantyńskich pisarzy okazuje się być nieprawdziwa. Pewne obserwacje dotyczące np. reakcji organizmu na przyjmowanie konkretnych składników w pożywieniu, czy lekarstwie, pozostają aktualne. Natomiast trafność wytłumaczenia przyczyn takich reakcji jest już odrębną kwestią, przy której dawni lekarze wypadają gorzej.

${ }^{188}$ W tym sensie dzieła Orybazjusza byłyby dla historii medycyny tym, czym dla historii literatury są Deipnosofiści Atenajosa z Naukratis (przy zachowaniu oczywistych proporcji w wykorzystanym przez obu autorów materiale). 


\section{WORKS OF ORIBASIUS AS A SOURCE OF INFORMATION ON FOOD IN THE LATER ROMAN EMPIRE}

\section{(Summary)}

The article makes an attempt at the presentation of medical works written by Oribasius (ca. 325 - ca. 400 A.D.), well educated physician from Pergamon, and a close friend of Julian the Apostate. It discusses the content of the treatises, reasons for their compiling and circumstances accompanying the creation of three of his extant writings, notably Collectiones medicae, Synopsis ad Eustathium filium, and Libri ad Eunapium. Moreover, the study presents available information about his lost medical work, whose title is now unknown. The authors focused on these parts of Oribasius' works, which concern food and dietetic, i.e. five books of Collectiones medicae (from I to V), book IV of Synopsis ad Eustathium filium and a part of book I of Libri ad Eunapium. The above-mentioned books enlist the most important foods like cereals, cereal products (breads, cakes, groats, pancakes), vegetables, fruits, meats, fishes, and seafood, dairy products, soft and alcoholic drinks as well as enumerating some specific diets and groups of food divided according to their properties or influence on human body.

An important part of the article is a succinct presentation of sources of Oribasius' dietetic expertise, and moreover a brief discussion of the medic's impact on medical systems in three different cultural circles, namely the Byzantine, Arab, and Latin. The authors' research corroborates the already existing view that major dietetic parts of Collectiones medicae, Synopsis ad Eustathium filium and Libri ad Eunapium are based on writings of Galen (which he, however, reworked with a view of their simplification), but there are many fragments taken from other authorities, for instance Pedanius Dioscurides, Athenaeus from Attalia, Diocles of Carystus, Rufus of Ephesus to mention but a few. As for medical authors, who excerpted or translated Oribasius' works, the most renowned are Aetius of Amida, Paul of Aegina, Alexander of Tralles, Hunayn ibn Ishāq, and the representatives of the medical school of Salerno.

Finally, the authors claim, that Oribasius' heritage is important especially for two reasons. First of all, it helped preserve a large amount of citations from ancient works, which today are lost, and known only thanks to the physician's painstaking work. Secondly, it contains a cornucopia of information about food, which reflect culinary habits of Late Roman society, and specifically of the Late Roman food market.

Słowa kluczowe: pisma Orybazjusza, antyczna i bizantyńska medycyna, antyczna gastronomia.

Key words: works of Oribasius, ancient and Byzantine medicine, ancient gastronomy. 
